\title{
Pemberdayaan masyarakat melalui pembentukan kelompok tani sehat berbasis potensi lokal di Kelurahan Sialang Sakti, Kecamatan Tenayan Raya, Pekanbaru
}

\author{
${ }^{1}$ Fakultas Kedokteran, Universitas Riau \\ ${ }^{2}$ Fakultas Teknik, Universitas Riau \\ ${ }^{3}$ Fakultas Ekonomi dan Bisnis, Universitas Riau \\ * eldanazriati@gmail.com
}

Elda Nazriati**', Sri Wahyuni ${ }^{1}$, Herisiswanto ${ }^{2}$, Rofika ${ }^{3}$, Zulharman ${ }^{1}$, Rita Endriani ${ }^{1}$

\begin{abstract}
Abstrak. Singkong merupakan salah satu bahan pangan pengganti beras yang cukup penting peranannya dalam menopang ketahanan pangan suatu wilayah, tetapi diversifikasi pangan berbahan dasar singkong masih perlu ditingkatkan. Tanggung jawab kesehatan dalam pelaksanaan pengamanan keamanan pangan dilaksanakan dengan menyusun acuan standar dan persayaratan teknis kesehatan seluruh proses pengelolaan rantai pangan memenuhi prinsip prinsip Higiene Sanitasi. Sialang Sakti adalah salah satu kelurahan di Kecamatan Tenayan Raya ini merupakan salah satu desa penghasil singkong yang potensial untuk dikembangkan. Tujuan kegiatan pengabdian meliputi pembentukan kelompok tani yang fokus pada singkong yang sekaligus berfungsi sebagai wadah promosi Gerakan hidup sehat. Kegiatan yang dilakukan berupa advokasi kepada pihak terkait, Focus Group Discussion (FGD), pembentukan kelompok tani, pelatihan-pelatihan, dan kegiatan lainnya untuk mendukung upaya promosi gerakan masyarakat sehat. Hasil kegiatan adalah terbentuknya kelompok tani yang fokus pada singkong dan promosi Germas, terjadinya peningkatan pengetahuan dan keterampilan budidaya singkong, dan adanya produk teknologi tepat guna, dan kemiteraan dengan pihak terkait.
\end{abstract}

Kata kunci: germas, kelompok tani, singkong

\begin{abstract}
Cassava is one of the foodstuffs whose role is quite important in supporting the food security of a region, but the diversification of food made from cassava still needs to be improved. Health responsibility in the implementation of food security is carried out by compiling reference standards and technical health requirements throughout the food chain process, the principles of Sanitation Hygiene. Sialang Sakti is one of the sub-districts in Tenayan Raya District and is one of the potential cassava producing villages to be developed. The purpose of the service activities included ordering farmer groups that focus on the environment which also functions as a promotion forum for the Healthy Living Movement. Activities carried out in the form of advocacy to related parties, Focus Group Discussion (FGD), ordering farmer groups, trainings, and other activities to support efforts to promote the healthy community movement. The result of the activity was the formation of farmer groups that focus on cassava and health promotion, increased knowledge and skills of cassava cultivation, and the presence of appropriate technology products, and partnership with related parties.
\end{abstract}

Keywords: health promotion, farmer groups, cassava

To cite this article: Nazriati, E., S. Wahyuni., Herisiswanto., Rofika., Zulharman., \& R. Endriani. 2020.

Pemberdayaan masyarakat melalui pembentukan kelompok tani sehat berbasis potensi lokal di Kelurahan Sialang

Sakti, Kecamatan Tenayan Raya, Pekanbaru. Unri Conference Series: Community Engagement 2: 139-145.

https://doi.org/10.31258/unricsce.2.139-145

(C) 2020 Authors

Peer-review under responsibility of the organizing committee of Seminar Nasional Pemberdayaan Masyarakat 2020 


\section{PENDAHULUAN}

Singkong merupakan salah satu bahan pangan pengganti beras yang cukup penting peranannya dalam menopang ketahanan pangan suatu wilayah. Singkong muncul sebagai makanan pokok yang dominan, terutama di daerah tropis lembab dan sub-lembab di banyak negara Afrika dan digunakan oleh orang-orang di mana terjadi kelangkaan makanan dan kekurangan pangan (Bayata A. 2019).

Permintaan singkong terus meningkat baik untuk konsumsi, pakan ternak, dan industri olahan (gaplek, chips, tapioka dan tepung kasava), serta bahan energi baru terbarukan. Demi keamanan pangan suatu wilayah perlu sosialisasi diversifikasi pangan berbahan singkong sebagai bahan pangan alternative selain beras atau jagung. Pembinaan UMKM khususnya pada pemanfaatan umbi-umbian lokal terbukti meningkatkan pendapatan masyarakat (Julianti, 2018; Sandyatma,2013). Meskipun potensi singkong sangat besar untuk diolah menjadi berbagai bahan pangan, tetapi diversifikasi pangan berbahan dasar singkong masih perlu ditingkatkan. (Sandyatma,2015; setyowati,2015). Selain sebagai makanan yang bernutrisi singkong juga mengandung beberapa anti nutrisi yang berpengaruh pada kesehatan manusia bila tertelan dalam jumlah tinggi, sehingga pengolahannya juga harus memenuhi syarat Kesehatan (Bayata A. 2019).

Perkembangan luas panen Singkong di Indonesia selama kurun waktu 1980-2016 berfluktuasi dengan kecenderungan mengalami penurunan, Perkembangan luas panen selama lima tahun terakhir cenderung menurun yaitu 8,98\% per tahun (Widaningsih,2016). Produksi Singkong di Indonesia terkonsentrasi di 8 (delapan) provinsi dengan kontribusi produksi sebesar 91,21\%. Riau bukanlah termasuk sepuluh provinsi sebagai sentra Singkong, tetapi Riau adalah provinsi urutan ke empat dalam produksi singkong perhektar yaitu 277, $714 \mathrm{Ku} / \mathrm{Ha}$. (Widaningsih,2016).

Banyak masyarakat yang masih beranggapan bahwa singkong merupakan makanan yang rendahan, meskipun demikian singkong mempunyai nilai gizi yang cukup baik dan sangat diperlukan untuk menjaga kesehatan tubuh, sebagai bahan pangan terutama sebagai sumber karbohidrat (Widianta, dalam Widaningsih, 2016). Permintaan akan umbi-umbian lokal meningkat karena masyarakat sudah mulai mencari makanan yang sehat. Singkong mengandung air sekitar 60\%, pati 25\%-35\%, serta protein, mineral, serat, kalsium, dan fosfat. Singkong merupakan sumber energi yang lebih tinggi dibanding padi, jagung, ubi jalar, dan sorgum. Beberapa keunggulan singkong adalah kadar gizi makro (kecuali protein) dan mikro tinggi, sehingga sejumlah penderita anemia dan kekurangan vitamin A dan C ditengah masyarakat yang pangan pokoknya singkong relatif sedikit. Daun mudanya berkadar gizi makro dan mikro paling tinggi dan proporsional dibandingkan dengan bahan sayuran lainnya. Kadar glikemik dalam darah rendah dan kadar serat pangan larut tinggi. Dalam usus dan lambung berpotensi menjadi probiotik, serta secara agronomis mampu beradaptasi terhadap lingkungan marginal sehingga merupakan sumber kalori potensial di wilayah yang didominasi oleh lahan marginal dan iklim kering. (Widaningsih,2016).

Germas adalah sebuah gerakan yang bertujuan untuk memasyarakatkan budaya hidup sehat. Pemerintah telah mencanangkan Germas sejak tahun 2015, tetapi sebagian masyarakat belum melaksanakan dan belum memahami arti pentingnya dalam kehidupan yang berkualitas. Dalam kampanye Germas salah satu hal yang dikampanyekan adalah tingkat mengkonsumsi sayur dan buah, terutama sayur dan buah lokal. Konsumsi sayuran dan buah-buahan yang cukup merupakan salah satu indikator sederhana gizi seimbang. Tanggung jawab kesehatan dalam pelaksanaan pengamanan keamanan pangan dilaksanakan dengan menyusun acuan standar dan persayaratan teknis kesehatan. Seluruh proses pengelolaan rantai pangan, harus memenuhi prinsip prinsip Higiene Sanitasi Pangan (HSP) baik terhadap orang, alat, bahan dan tempat pengelolaannya (Pusdatin kemenkes, 2015). Laporan Badan Pengawasan Obat dan Makanan tahun 2018 menunjukkan dari 134 sarana industri rumah tangga menunjukkan hasil 17 sarana telah memenuhi ketentuan sedangkan 117 sarana bernilai kurang, pemeriksaan sampel makanan menunjukkan memenuhi syarat $(75.11 \%)$ dan tidak memenuhi syarat sebanyak (24.89\%). Produk pangan tersebut dikatakan tidak memenuhi syarat karena mengandung bahan berbahaya, cemaran mikroba atau bahan tambahan pangan (BTP) yang kadarnya melebihi batas maksimum yang diizinkan (BPOM, 2018). Berbagai penelitian menunjukkan pemberdayaan masyarakan dalam promosi Germas sangat efektif (Syam,2019), untuk itu perlu fasilitasi dari berbagai pihak agar peran serta masyarakat pada program ini dapat berjalan optimal. Pemberdayaan ini dapat berjalan lebih baik dengan dukungan potensi lokal yang meningkatkan perekonomian masyarakat.

Sialang Sakti adalah salah satu kelurahan di Kecamatan Tenayan Raya Kota Pekanbaru Provinsi Riau. Kelurahan Sialang Sakti merupakan satu dari daerah pemekaran di Kecamatan Tanayan Raya. Lahan pertanahan di Sialang sakti cukup subur, sebagaian masyarakat menanam berbagai tanaman termasuk singkong. Kontur tanah bervariasi berupa dataran dan perbukitan. Letaknya yang berada di pinggir kota 
Pekanbaru mempermudah untuk mendapatkan berbagai fasilitas dan informasi. Kelurahan ini merupakan salah satu desa penghasil singkong yang potensial untuk dikembangkan serta mendukung program pemerintah melalui pemanfaatan potensi lokal.

Rumusan masalah adalah belum adanya wadah pemberdayaan masyarakat yang pemanfaatan singkong sebagai upaya ketahanan pangan keluarga sekaligus sebagai promosi gerakan masyarakat hidup sehat di kelurahan Sialang sakti Kecamatan Tenayan Raya. Tujuan kegiatan pengabdian meliputi pembentukan kelompok tani yang fokus pada singkong yang sekaligus berfungsi sebagai wadah promosi Gerakan hidup sehat. Wadah ini diharapkan dapat berkembang ke depan untuk meningkatkan kemampuan masyarakat dalam membuat makanan keluarga yang sehat dan higienis melalui diversifikasi pangan berbasis singkong, dan meningkatkan kemampuan masyarakat untuk memanfaatkan singkong dalam industri rumah tangga.

Masyarakat sasaran pada kegiatan pengabdian ini adalah ibu rumah tangga dan kelompok petani di kelurahan Sialang Sakti Kecamatan Tenayan Raya Kota Pekanbaru. Lokasi pengabdian berjarak 20 kilometer dari kampus Universitas Riau.

\section{METODE PENERAPAN}

Kegiatan pengabdian direncanakan selama tiga tahun, tahun pertama adalah pembentukan kelompok tani $\mathrm{Si}$ AKANG, tahun kedua adalah penguatan anggota dalam Germas dan diversifikasi makanan sehat dan higienis berbahan dasar singkong dan tahun ketiga adalah penguatan pada Si AKANG menjadi agen perubahan dalam implementasi Germas dan pengembangan industri rumah tangga berbahan dasar singkong.

Pada makalah ini yang akan dilaksanakan adalah kegiatan tahun pertama yaitu pembentukan "Si Akang" (singkong andalan keluarga berkembang) sebagai wadah kegiatan promosi gerakan masyarakat sehat (Germas). "Si Akang" adalah organisasi kemasyarakatan yang bergerak dibidang promosi hidup sehat dengan memanfaatkan sumber daya lokal berupa tanaman singkong. Kegiatan yang dilakukan pada tahun pertama berupa advokasi kepada pihak terkait, Focus Group Discussion (FGD), pencanangan Si AKANG dan peresmian Posko Si Akang, pelatihan-pelatihan, dan kegiatan lainnya untuk mendukung upaya promosi gerakan masyarakat sehat.

Alat ukur ketercapaian meliputi :

pembentukan kelompok tani

Peningkatan pengetahuan dan keterampilan pengurus dan anggota "Si Akang".

Jumlah produk yang dihasilkan berupa panduan, dan bahan pangan berbasis singkong

Jumlah anggota yang terdaftar dan aktif

Perubahan sikap, sosial budaya, dan ekonomi masyarakat sasaran.

Ketercapaian program diukur melalui observasi dan FGD untuk melihat capaian kegiatan secara kuantitatif dan kualitatif.

\section{HASIL DAN KETERCAPAIAN SASARAN}

\section{Hasil}

Kegiatan pengabdian kepada masyarakat dilakukan pada tahun 2020. Adapun kegiatan yang dilaksanakan berupa:

\section{Advokasi kepada pihak terkait.}

Pada tahun pertama implementasi kegiatan meliputi pembentukan "Si AKANG" ( singkong andalan keluarga berkembang). "Si AKANG" adalah organisasi kemasyarakatan yang bergerak di bidang promosi hidup sehat dengan memanfaatkan sumber daya lokal berupa tanaman singkong. Kegiatan yang dilakukan pada tahun pertama berupa: Pembentukan "Si AKANG" diawali dengan advokasi dengan mitra kegiatan yaitu aparat pemerintah kelurahan Sialang Sakti, Puskesmas Rejosari, dan organisasi kewanitaan Salimah cabang Tenayan Raya untuk untuk memperoleh informasi yang berkaitan dengan kondisi terkini tentang program GERMAS dan pemanfaatan singkong di Kelurahan Sialang Sakti. Secara umum seluruh pihak sangat mendukung rencana pembentukan Si AKANG dan siap mendukung sesuai kapasitas masing-masing.

\section{Focus Group Discussion (FGD)}

Selanjutnya dilakukan Focus Group Discussion (FGD) untuk menggali sumberdaya yang ada, peran masingmasing mitra dan rencana kegiatan yang akan dilakukan. FGD mengundang ibu RW 02 Kelurahan Sialang 
Sakti dan ibu-ibu lainnya yang diperkirakan antusias untuk membentuk Si AKANG. Pada kegiatan tersebut beberapa hal yang dihasilkan adalah:

Menggali sumber daya yang ada. Diketahui bahwa kelompok tani pernah terbentuk tetapi tidak focus pada tanaman singkong. Saat ini kelompok tani tidak aktif, dan anggotanya bertani secara mandiri. Beberapa ibu berminat untuk membentuk kelompok tani di bawah pembinaan tim pengabdian kepada masyarakat Universitas Riau.

Melakukan Sosialisasi tentang Si AKANG yang akan dibentuk, yaitu sebuah kelompok tani yang focus pada singkong sebagai sumberdaya lokal sekaligus sebagai stimulasi gerakan masyarakat sehat.

Membentuk struktur organisasi pengurus, pembina, dan meminta kesediaan Lurah Sialang Sakti untuk menerbitkan SK Si AKANG.

Merencanakan letak posko Si AKANG dan melakukan perekrutan anggota Si AKANG. Anggota " Si AKANG" adalah ibu rumah tangga, petani singkong, remaja putri yang berminat untuk mempromosikan gaya hidup sehat dan mengembangkan potensi singkong sebagai makanan sehat dan industri rumah tangga. Pengurus bersedia mengikuti pelatihan dan pembinaan untuk menjalankan program Si AKANG

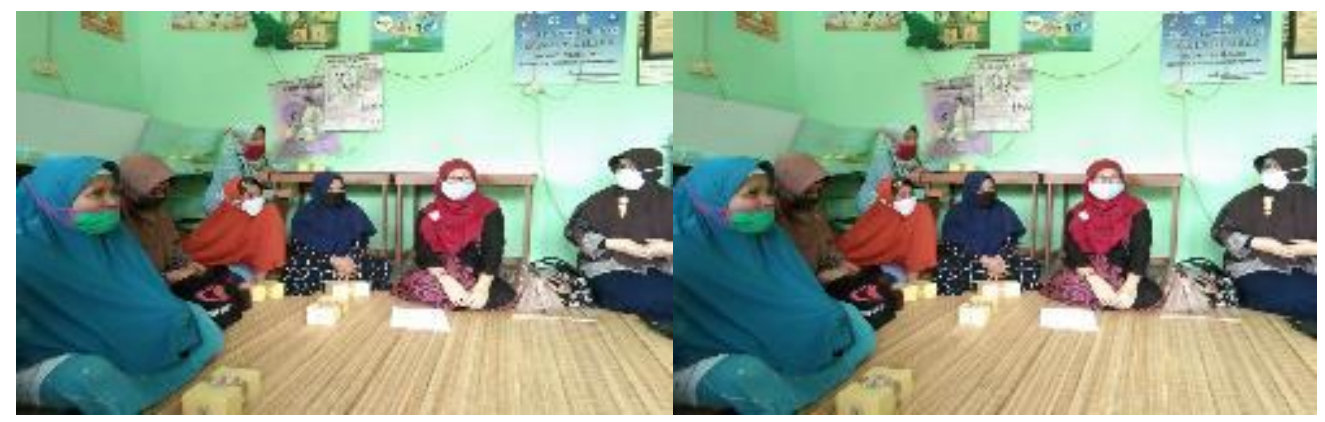

Gambar 1. Focus Group Discussion (FGD)

\section{a. Pencanangan Si AKANG dan Peresmian Posko Si AKANG}

Pencanangan Si AKANG dan peresmian posko SiAKANG dilaksanakan pada 22 Juli 2020 dengan mengundang Pembina Si AKANG yaitu Puskesmas Rejosari dan organisasi kewanitaan Salimah. Kegiatan ini bertujuan untuk memperkenalkan Si AKANG pada masyarakat sekaligus meminta dukungan kepada pihakpihak terkait. Peresmian dilakukan oleh Lurah Sialang Sakti dengan membuka selubung papan nama Si AKANG dan pengguntingan pita dilanjutkan dengan mengunjungi posko Si AKANG. Pada kegiatan tersebut juga diserahkan Surat Keputusan pengurus Si AKANG oleh Lurah Sialang Sakti bapak H Hasan Nusi, SE sekaligus pelantikan pengurus. Selain itu juga dilakukan penyerahan alat kelengkapan organisasi seperti alat tulis, stempel, kop surat, papan struktur organisasi, USB, dan sejumlah buku administrasi.

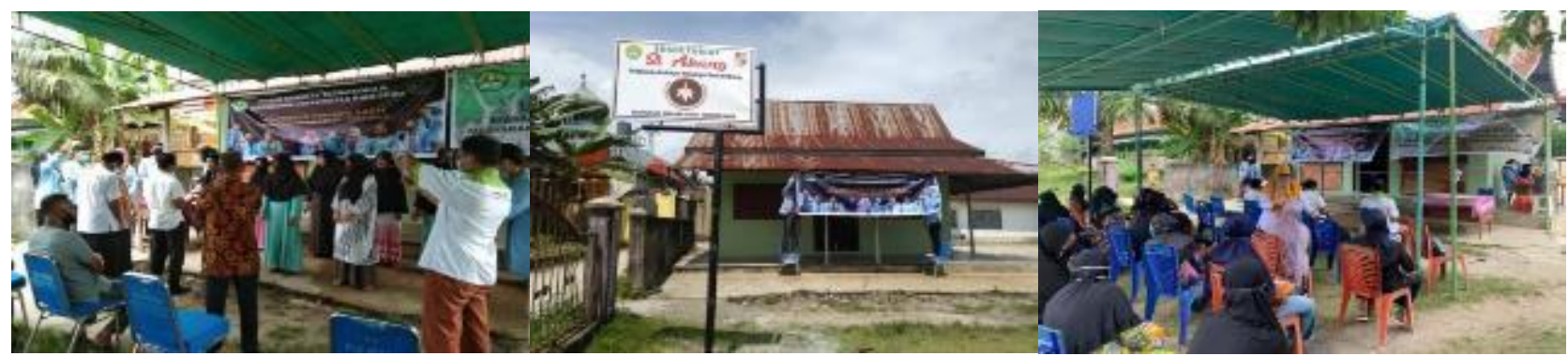

Gambar 2. Pencanangan Si AKANG dan Peresmian Posko

\section{b. Pelatihan-pelatihan dan Praktik.}

Pelatihan yang dilakukan meliputi pelatihan manajemen organisasi dan kemiteraan kelompok tani, kandungan nutrisi singkong, dan budidaya singkong. Narasumber pelatihan berasal dari tim pengabdian dan mengundang narasumber dari departemen pertanian. pelatihan ini dilanjutkan dengan praktik menyiapkan lahan, memilih bibit, menanam dan merawat tanaman singkong. Sementara menunggu tanaman singkong dapat dipanen dilakukan pula pembuatan keripik singkong yang akan dipasarkan secara terbatas untuk mendapatkan masukan sekaligus berlatih kewirausahaan. Selain itu juga dihasilkan buku panduan budidaya singkong dan alat perajang singkong yang diserahkan kepada kelompok tani. 


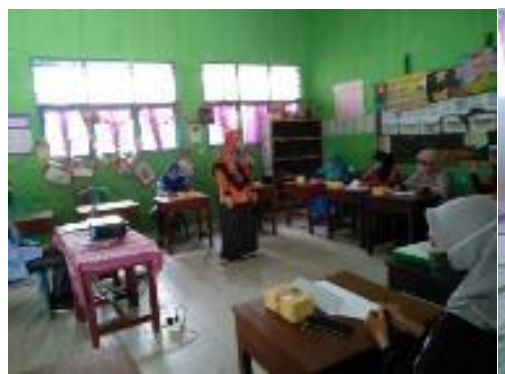

(a) manajemen organisas

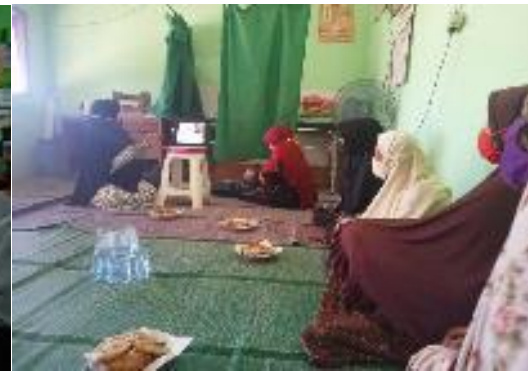

(b) kandungan nutrisi singkong Gambar 3. Pelatihan-pelatihan

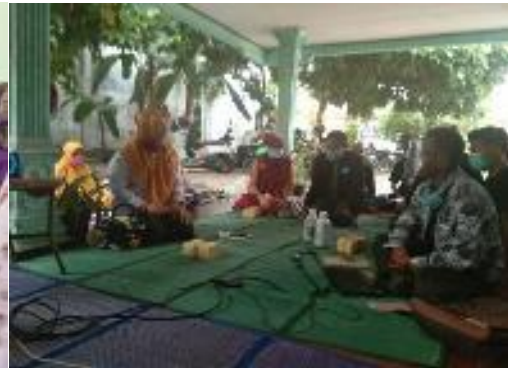

(c) budidaya singkong

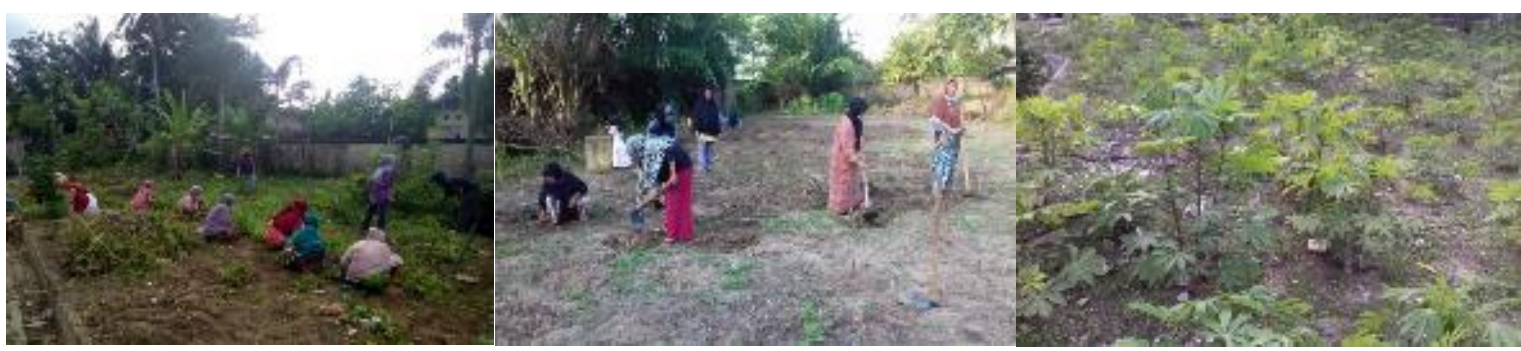

Gambar 4. Praktik penyiapan lahan, penanaman, dan perawatan tanaman singkong

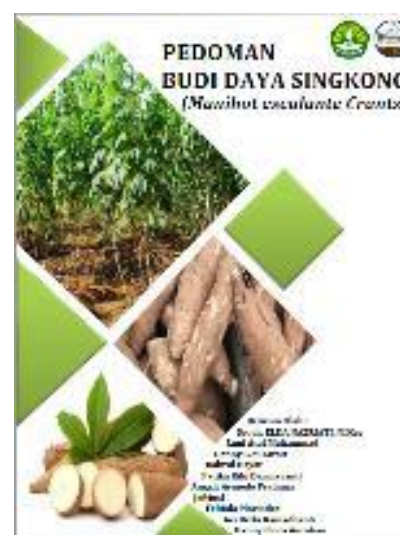

(a)

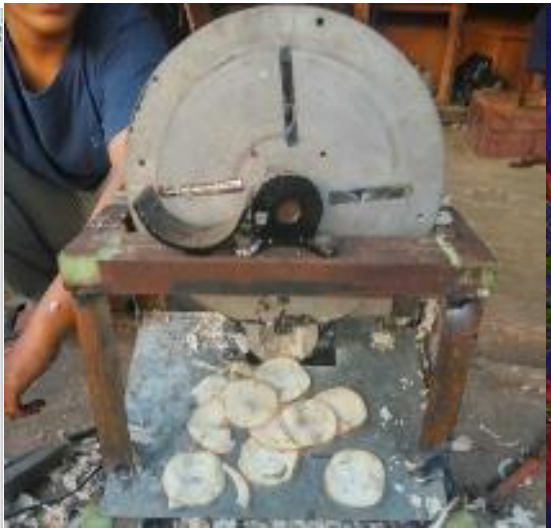

(b)

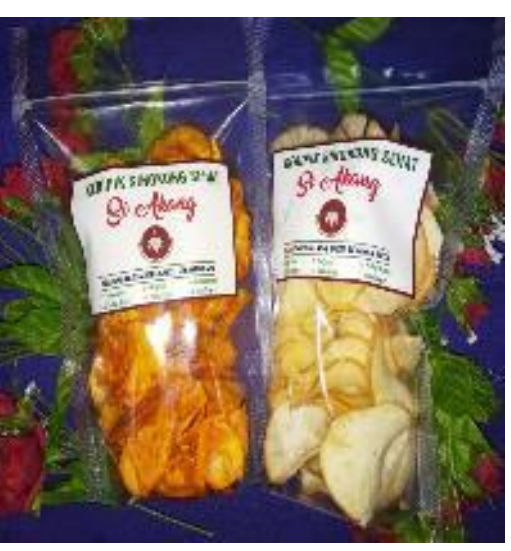

(c)

Gambar 5. Produk yang dihasilkan (a) buku panduan budidaya singkong berISBN, (b) mesin perajang singkong dan (c) keripik singkong,)

\section{c. Kegiatan Germas}

Kegiatan Germas yang dilakukan antara lain pemeriksaan jentik nyamuk Aedes, penataan Tanaman Obat Keluarga, penyuluhan kesehatan secara online dan offline, serta olahraga bersama masyarakat. Kegiatan ini dilakukan secara terintegrasi dengan mahasiswa Kukerta Universitas Riau.

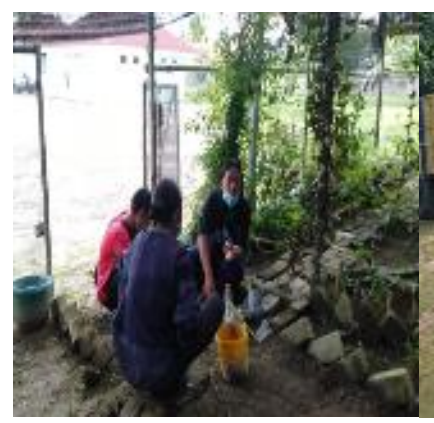

(a)

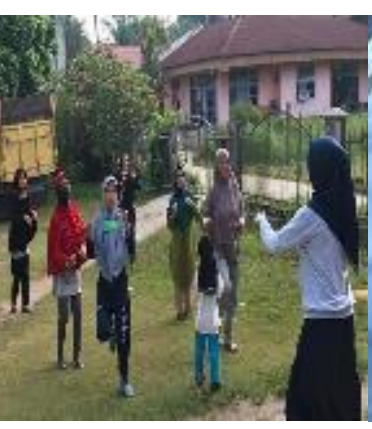

(b)

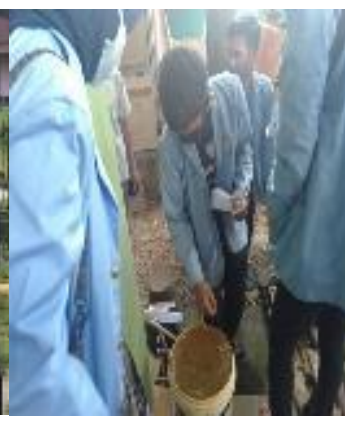

(c)

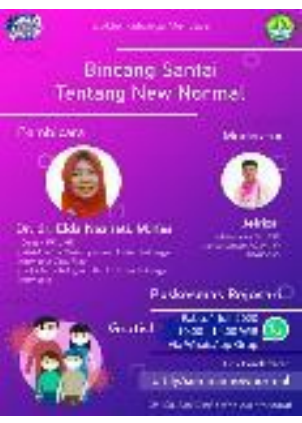

(d)

Gambar 6. Kegiatan Gerakan masyarakat sehat (Germas) ((a) penataan taman obat keluarga (toga), (b) Olahraga (c) pemeriksaan jentik nyamuk, (d) seminar online,) 


\section{Tingkat Ketercapaian Sasaran Program}

Tingkat ketercapaian program disajikan pada tabel berikut :

Tabel 1. Tingkat ketercapaian program

\begin{tabular}{|c|c|c|c|}
\hline No & Indikator & Sebelum & Sesudah \\
\hline 1. & $\begin{array}{l}\text { Pembentukan kelompok tani } \\
\text { dan perekrutan anggota }\end{array}$ & Tidak ada & $\begin{array}{l}\text { Ada dan berfungsi baik } \\
\text { Fokus pada singkong } \\
\text { Anggota } 18 \text { orang }\end{array}$ \\
\hline \multirow[t]{3}{*}{2.} & Peningkatan pengetahuaan & $\begin{array}{l}\text { Tidak tahu manfaat kelompok tani } \\
\text { Tidak tahu kelebihan kandungan } \\
\text { singkong } \\
\text { Bertani singkong secara tradisional }\end{array}$ & $\begin{array}{l}\text { Tahu bahwa kelompok tani } \\
\text { penting untuk } \\
\text { mengembangkan berbagai } \\
\text { macam potensi termasuk } \\
\text { kemiteraan }\end{array}$ \\
\hline & & & $\begin{array}{l}\text { Tahu cara budidaya singkong } \\
\text { yang lebih baik (penyiapan } \\
\text { lahan, memilih bibit, } \\
\text { pemeliharaan, potensi pasca } \\
\text { panen) }\end{array}$ \\
\hline & & & $\begin{array}{l}\text { Tahu kandungan nutrisi } \\
\text { singkong dengan lebih baik }\end{array}$ \\
\hline \multirow[t]{6}{*}{3.} & Produk/praktik & $\begin{array}{l}\text { membuat keripik singkong sendiri- } \\
\text { sendiri } \\
\text { menanam herhagai macam tanaman }\end{array}$ & $\begin{array}{l}\text { keripik singkong } \\
\text { berkelompok, ada merk dan } \\
\text { rencana pemasaran lebih luas }\end{array}$ \\
\hline & & yang dikehendaki & $\begin{array}{l}\text { melakukan penanaman } \\
\text { singkong dengan lebih } \\
\text { terstruktur dan pengetahuan } \\
\text { yang baik (menyiapan lahan, } \\
\text { pemilihan bibit, perawatan } \\
\text { tanaman) }\end{array}$ \\
\hline & & & $\begin{array}{l}\text { buku panduan bududaya } \\
\text { singkong berISBN }\end{array}$ \\
\hline & & & Alat perajang singkong \\
\hline & & & kegiatan promosi Germas \\
\hline & & & $\begin{array}{l}\text { Melakukan pengelolaan } \\
\text { kelompok tani dengan } \\
\text { administrasi yang lebih baik }\end{array}$ \\
\hline 4. & Kemiteraan & Tidak ada & $\begin{array}{l}\text { Kelurahan, Puskesmas, } \\
\text { departemen pertanian, } \\
\text { organisasi kewanitaan }\end{array}$ \\
\hline
\end{tabular}

\section{KESIMPULAN}

Telah dilakukan kegiatan pengabdian masyarakat berupa pembentukan Si AKANG sebagai wadah gerakan masyarakat sehat dengan memanfaatkan potensi lokal yaitu singkong. Kegiatan berupa pembentukan organisasi kemasyarakan Si AKANG, pelatihan manajemen organisasi dan kemiteraan, seminar kandungan nutrisi singkong, dan budidaya singkong. Kegiatan penunjang lainnya adalah gerakan masyarakat sehat berupa senam , pemeriksaan jentik, dan penyuluhan kesehatan. juga dihasilkan buku panduan dan mesin perajang singkong, serta bantuan serta alat-alat pertanian. Seluruh kegiatan berjalan lancar dan mendapat dukungan dari pihak terkait, Kendala yang dihadapi berupa pandemi covid19 sehingga peserta seluruh kegiatan dibatasi 
jumlahnya untuk tetap menjaga protokol kesehatan. Si AKANG belum mempunyai gedung sekretariat sendiri, untuk sementara bergabung dengan gedung posyandu, akibatnya peralatan-peralatan yang membutuhkan ruang dititipkan di rumah pengurus. Dukungan pemerintah setempat sangat dibutuhkan agar kelompok tani ini dapat berkembang lebih optimal khususnya pada penyediaan gedung sekretariat sendiri.

Diharapkan kegiatan ini dapat berlanjut di tahun kedua dan ketiga sehingga kelompok tani Si AKANG akan menjadi kelompok tani mandiri yang dapat mengangkat perekonomian masyarakat dan mempromosikan gerakan hidup sehat.

\section{UCAPAN TERIMA KASIH}

Tim Pengabdian mengucapkan terima kasih kepada Rektor Universitas Riau melalui LPPM Unri yang telah menyediakan dana kegiatan dengan kontrak no 908/UN.19.5.1.3/PT.01.03/2020. Terima kasih pula atas dukungan Lurah Sialang Sakti, Puskesmas Rejosari, dan organisasi wanita Salimah cabang Tenayan Raya serta khususnya ibu-ibu pengurus dan anggota kelompok tani SiAKANG.

\section{DAFTAR PUSTAKA}

Bayata A. 2019. Review on Nutritional Value of Cassava for Use as a Staple Food. Science Journal of Analytical Chemistry, 7(4), 83-91. doi: 10.11648/j.sjac.20190704.12

BPOM Padang. 2018. Laporan Tahunan Balai Besar POM Padang. Padang, BPOM Padang 2018

Julianti, E., Ridwansyah, T. Karo-Karo, dan Halimatuddahliana. 2018. Diversifikasi produk melalui pemanfaatan tepung umbi-umbian lokal sebagai pengganti terigu pada UKM produk bakery di Kota Binjai. Riau Journal of Empowerment, 1(2), 75-83 https://doi.org/10.31258/raje.1.2.10

Kementerian Kesehatan RI. 2015. Buku Panduan GERMAS Gerakan Masyarakat Hidup Sehat. , Jakarta. Kementerian Kesehatan RI. pp.1-24.

Sandyatma, YH.2015.Pemantapan ketahanan pangan melalui diversifikasi pangan berbasis pemberdayaan masyarakat. Buletin Jendela Data dan Informasi Kesehatan. semester II : 23-9

Setyowati E. Peningkatan dan Pembinaan Pangan siap saji dalam rangka menciptakan jaminan mutu pangan yang aman dan sehat. Buletin Jendela Data dan Informasi Kesehatan. 2015 semester II: 19-22

Syam NS, Nurfita D, Rahayu A, 2019. Pelatihan pemanfaatan buah dan sayur untuk mendukung program gerakan masyarakat sehat (Germas) pada kader 'Aisyiyah Banguntapan Utara. Jurnal Pemberdayaan: Publikasi Hasil Pengabdian kepada Masyarakat, 3(1), 97-102. DOI: https://doi.org/10.12928/jp.v3i1.569

Widaningsih R. 2016. Outlook Komoditas Pertanian Tanaman Pangan Ubi Kayu. Jakarta. Pusat Data Dan Sistem Informasi Pertanian Kementerian Pertanian 